\title{
Determinants of the variability of corporate effective tax rates (ETRs): evidence for the Netherlands
}

Citation for published version (APA):

Janssen, J. B. P. E. C., \& Buijink, W. F. J. (2000). Determinants of the variability of corporate effective tax rates (ETRs): evidence for the Netherlands. METEOR, Maastricht University School of Business and Economics. METEOR Research Memorandum No. 046 https://doi.org/10.26481/umamet.2000046

Document status and date:

Published: 01/01/2000

DOI:

10.26481/umamet.2000046

Document Version:

Publisher's PDF, also known as Version of record

\section{Please check the document version of this publication:}

- A submitted manuscript is the version of the article upon submission and before peer-review. There can be important differences between the submitted version and the official published version of record. People interested in the research are advised to contact the author for the final version of the publication, or visit the DOI to the publisher's website.

- The final author version and the galley proof are versions of the publication after peer review.

- The final published version features the final layout of the paper including the volume, issue and page numbers.

Link to publication

\footnotetext{
General rights rights.

- You may freely distribute the URL identifying the publication in the public portal. please follow below link for the End User Agreement:

www.umlib.nl/taverne-license

Take down policy

If you believe that this document breaches copyright please contact us at:

repository@maastrichtuniversity.nl

providing details and we will investigate your claim.
}

Copyright and moral rights for the publications made accessible in the public portal are retained by the authors and/or other copyright owners and it is a condition of accessing publications that users recognise and abide by the legal requirements associated with these

- Users may download and print one copy of any publication from the public portal for the purpose of private study or research.

- You may not further distribute the material or use it for any profit-making activity or commercial gain

If the publication is distributed under the terms of Article $25 \mathrm{fa}$ of the Dutch Copyright Act, indicated by the "Taverne" license above, 


\title{
Determinants of the Variability of Corporate Effective Tax Rates (ETRs): Evidence for the Netherlands
}

\author{
Boudewijn Janssen* \\ Willem Buijink
}

version 2-8-00

preliminary and incomplete

MARC Working Paper MARC-WP/3/2000-08

\footnotetext{
*MARC and Department of Accounting and Finance, Faculty of Economics and Business Administration, Universiteit Maastricht (PO Box 616, 6200 MD Maastricht, The Netherlands). We thank Jos Blommaert, Henk Brink, David Guenther, Kevin Holland, Gerard Kampschröer and Frank Moers for their helpful remarks on an earlier version of this paper.
} 


\begin{abstract}
A sizeable portion of US research has tried to assess the 'fairness' of the corporate income tax system, that is: are companies treated in a non-discriminatory way under the corporate income tax system. Similar research has, however, never taken place in the Netherlands. The goal of this paper is to address this shortcoming. This paper examines whether an association can be found between the variation in average effective tax rates (ETRs) among Dutch companies and company characteristics such as size, asset mix, extent of foreign operations, performance, leverage, being a public company and being a listed company. Controls are used for net operating loss status, negative tax expense status, and interaction between firm size and net operating loss status and negative tax expense status. The results in the paper are based on an analysis of a pooled panel of company-level data from financial statements in the CD-ROM REACH A datafile for five years, 1994 to 1998. In this paper two financial statement based ETR measures are used. One ETR measure is based on income before taxes and another ETR measure is based on cash flow. Results from a fixed effects generalised linear model provide support for the conclusion that, after controlling for indirect effects, the taxation of corporate profits in the Netherlands is fairly neutral. These results are supported by additional sensitivity analysis.
\end{abstract}




\section{Introduction and motivation.}

Large companies in particular have been the target of allegations that they do not pay their fair share of the tax burden. Political action groups voiced these allegations during the 1980's, especially in the United States ${ }^{1}$, but also as recently as 1998 in the Netherlands (Banning and Meeus, 1998). Some of these claims are based on research measuring corporate level average Effective Tax Rates (ETRs). ETR is a measure of a company's tax burden generally calculated as (current or total) income tax expense over before-tax financial accounting income. The CTJ research showed that ETRs for the largest US companies were below those for smaller companies, where the tax rate schedules facing these companies were the same. It is thought that the pressure from the political action groups, in particular the Citizens for Tax Justice movement, has led to many of the corporate income tax changes in the US Tax Reform Act of 1986, effectively eliminating various tax preferences.

Although the US political action groups based their allegations on research, this research can be, and has been, criticized. One major criticism is that size of a company is almost certainly not the only determinant of differences in corporate ETRs. Academic research investigating various company characteristics as determinants of ETRs, not just company size, using company level data has been undertaken by Stickney and McGee (1982) and subsequent papers. The most recent contributions are Gupta and Newberry (1997) and Plesko (1999).

Our paper, using Dutch data, builds on this research. In the Dutch context the relevance of the question what determines the variability of company ETRs has also been noted (Banning and Meeus, 1998). The most recent example is the so-called technolease arrangement affair. Dutch tax authorities, in recent years, allowed Philips and Fokker to sell and lease back their technological knowledge in a deal with banks. This generated generous direct and indirect tax effects for the parties involved in the arrangement, affecting their ETRs ${ }^{2}$. However, for other companies the use of the arrangement was disallowed, invoking calls of inequitable tax treatment in the press. The question as to which factors determine the cross-section of company ETRs as well as the magnitudes of ETRs themselves is therefore also relevant in the Dutch context as this provides information on the level of tax preferences provided to companies. However, US research regarding determinants of ETRs has not been matched by Dutch research. A recent 
study (Belastingdienst, 1997) by the Dutch tax authorities does investigate cross-sectional differences between the company financial accounting tax expense and actual taxes paid. Although interesting, the study is descriptive and gives aggregated results ${ }^{3}$ only and thus provides no information on the differences observed in relation to company characteristics. We know of no other empirical research investigating Dutch company level ETRs.

This paper is therefore the first to provide information on the magnitude of ETRs and determinants of ETRs for Dutch companies. Furthermore, this paper uses a fixed effects generalised linear model enabling us to investigate nonlinear relationships between determinants and ETRs. Previous research has generally only looked at linear relationships by applying OLS regression methods. Due to Dutch financial accounting laws, both public and private companies have to disclose their financial statements, in contrast to the US where only public companies are required to disclose their financial statements. This allows us to investigate differences between public and private companies. The availability of financial statements of non-listed firms also allows us to investigate differences between listed and non-listed firms. We use company level panel data for five years from 1994 to 1998 . First, we find that ETRs are substantially below the statutory tax rates, indicating a substantial amount of tax preferencess provided to companies. Secondly, after controlling for the (in)direct effects of financial accounting losses and negative tax expenses we find the levying of corporate income taxes in the Netherlands fairly neutral. That is, we only find limited support for significant associations between company characteristics and ETR.

The remainder of this paper is organized as follows. Section 2 describes the previous research about the variability of ETRs and the hypotheses are developed in that section. Section 3 explains financial accounting for income taxes in The Netherlands. Section 4 discusses research methods: the source of our data, variable definitions and model specification. Results are given in section 5. The paper ends with a summary and concluding remarks in section 6 .

\section{Previous research and hypotheses development.}

\subsection{Previous research.}

Research on the determinants of the cross-section of ETRs with company level data begins with Stickney and McGee (1982). Before that, several papers had looked at ETR 
variability across industries with aggregated data. Callihan (1994) is a useful survey of ETR research up to 1994. As explained in Callihan there are two varieties of empirical ETR research: research into marginal ETRs and research into average ETRs. The marginal ETR for a specific investment is the rate of tax paid on an additional unit of income from a specific investment project. Marginal ETRs should be used to investigate the effect of taxation on investment decisions. Marginal ETRs can also be used at the level of a firm, but of course a firm is a collection of investment projects which makes the uses of marginal ETRs at that level problematic. For a discussion, see Callihan (1994, section 3.1.3). Average ETRs are better suited to express the overall tax burden on the company (Callihan, 1994). They express the rate of tax paid on the entire income. Our paper, because of its focus on the determinants of the variability of the tax burden across companies, looks at average ETRs. This review of previous research therefore focuses on average ETRs.

To provide structure for our discussion of existing company level average ETR research we use an approach developed by Wilkie (1988), that identifies categories of determinants of the variability of average ETRs across firms.

ETR is the ratio of tax expense (T) over financial accounting income (I) of a company. Thus,

$$
\mathrm{ETR}=\mathrm{T} / \mathrm{I}
$$

And tax expense $\mathrm{T}$ is taxable income $(\mathrm{TI})$ times the statutory tax rate $(\mathrm{t}): \mathrm{T}=\mathrm{TI} * \mathrm{t}$. Therefore,

$$
\mathrm{ETR}=[\mathrm{TI} * \mathrm{t}] / \mathrm{I}
$$

Wilkie (1988) then introduces the notion of tax preferences (TP), which is the difference between financial accounting income and taxable income: $\mathrm{TP}=\mathrm{I}-\mathrm{TI}$, hence TI=I-TP. Tax preferences include the timing and permanent differences between financial accounting income and taxable income. Below we will motivate the use of the term 'tax preference'. Substituting TI in (2) leads to $\mathrm{ETR}=[(\mathrm{I}-\mathrm{TP}) / \mathrm{I}]^{*} \mathrm{t}$, which simplifies to,

$$
\mathrm{ETR}=[1-\mathrm{TP} / \mathrm{I}] * \mathrm{t}
$$


for a company, and we have omitted the subscript.

Equation (3) shows how company ETRs are influenced by the variability across companies in tax preferences (TP), financial accounting income (I) and tax rate changes (t).

Equation (3) implicitly underlies previous research on the determinants of the cross-section of ETRs.

In previous research, tax preferences (TP) have been modelled as a function of company size and of a company's operating, financing, and investment decisions. Zimmerman (1983) suggested that larger companies will, because of their larger political visibility, have fewer tax preferences available to them than smaller firms. An interesting alternative rationale for such an effect is that suggested by Scholes and Wolfson (1992). They expect that large mature firms may find it difficult to aggressively pursue tax planning, because that may interfere with other tax impacted contracts. The counter argument is that larger companies have, or can buy, more tax expertise, or have more political clout to obtain advantageous tax preferences. Zimmerman (1983) did indeed find, as he expected, a positive effect of company size on ETRs. However, his findings were disputed by Porcano (1986) who found a negative effect on ETRs of company size. Wilkie and Limberg (1990) subsequently reconciled these different findings by pointing out relevant differences in the research designs of Zimmerman (1983) and Porcano (1986). Among them were differences in ETR definition. We will return to this point below. In a contemporaneous paper, Omer, Molloy and Ziebart (1990) make a similar methodological contribution. In a later paper, Shevlin and Porter (1992), after taking into account Wilkie and Limberg's (1990) remarks, still report the finding of progressive company income taxes, albeit in a univariate framework. Holland (1998) finds a positive size effect for the UK for a number of years in his twenty six year period. However, he also finds a few years with negative size effects.

Note however that neither Zimmerman (1983) nor Porcano (1986) studies the variation in ETRs in a multivariate framework whereas there are more firm characteristics potentially influencing tax preferences to companies. This point was made early by Stickney and McGee (1982) and recently by Gupta and Newberry (1997). Capital structure (i.e. leverage) can 
inversely affect ETRs (i.e. lower ETRs) because interest expenses are tax deductible, whereas dividends are not. Also, asset mix may impact ETRs inversely because of tax benefits often allowed for capital investment: investment credit or favourable tax depreciation schedules. Stickney and McGee (1982) have looked at both leverage and capital intensity in a multivariate framework and found the effects expected. Interestingly, for company size they found no effect. Gupta and Newberry (1987) used several asset mix variables and leverage in their multiple regression model explaining variability of ETRs. They also found the effects expected. Again, their results did not show a company size effect in a multivariate framework. Stickney and McGee (1982) also included the extent of foreign operations of a firm as an explanatory variable. The extent of foreign operations influences ETRs, for instance in the US context, through tax credits extended for foreign profits earned in more lightly taxed environments. They indeed found an inverse effect (more foreign operations, lower ETR). Gupta and Newberry did not include this variable. Stickney and McGee (1982) also model an impact of industry on ETRs. They point out that certain US industries (natural resources) are treated more favourably taxwise. They find the effect expected on ETRs. Gupta and Newberry did not use this variable. Zimmerman (1983) had already found that trade industries appear to have lower ETRs than manufacturing industries.

Because the focus in ETR research is on the cross-sectional distribution of tax preferences granted to companies, equation (3) suggests the use of company profitability as a control variable. Gupta and Newberry include return on total assets (ROA) in their model and document the expected positive (higher ROA, higher ETR) effect.

Other control variables suggested in the literature are a financial accounting loss (NOL) and a negative tax expense (NTE). NOLs proxy for negative taxable income. Negative taxable incomes create a tax shield lowering ETRs in different years. NOLs will directly confound the firm size effect on ETRs, when larger companies (i.e. more diversified companies) profit less from this type of tax shield. Furthermore, NOLs will also indirectly confound the firm size effect, as suggested by Wang (1991). Also, NOL and NTE can lead to negative ETRs, which are difficult to interpret. The occurrence of both NOL and NTE will lead to positive ETRs. To control for this a NOL*NTE control variable is used. To control for the indirect firm size effect, an interaction variable NOL*FSIZE is used. Since NTEs are a result from NOLs, the same 
procedure for NTEs is followed and an interaction variable NTE*FSIZE is applied. NOL, NTE, and the other control variables are treated as covariates in our model. Alternatives found in the literature, regarding the treatment of NOLs and NTEs, are to set ETRs for companies with either negative NOL and/or negative NTE to specific minimum or maximum values or to drop the companies involved from the sample. This however eliminates meaningful observations from the sample, possibly biasing the research design.

Equation (3) also suggests that tax rate changes will affect ETRs. Gupta and Newberry (1997) look at the effect of tax reform in the US in 1986 (the Tax Reform Act of 1986, TRA86) in the area of company income tax, by estimating their ETR model for a panel of firms preTRA86 and post-TRA86. Shevlin and Porter (1982) also investigate the effect of TRA86 on ETRs, and furthermore complement the measurement of ETRs by decomposing the observed changes into an income effect, a tax rate effect, and a tax rule effect. The Netherlands has, however, had no major changes in income tax rules or rates during the sample period.

Finally, the recent study by a working party of the Dutch tax authorities referred to above (Belastingdienst (1997)), documents the difference in aggregate between taxable income and financial accounting income for a sample of 1566 Dutch medium sized companies in 1992. The study uses tax return data, that are not publicly available, and finds that in aggregate taxable income is $57 \%$ of financial accounting income for the sample firms. It then investigates the causes of the aggregate difference in terms of the effect of tax preferences, but not in terms of company characteristics which trigger the application of these tax preferences. It also does not provide a cross-sectional analysis of how the aggregate difference is allocated to individual companies and therefore cannot look at how company level differences are related to company characteristics. However, the quantitative importance of the aggregate difference observed in 1992 provides additional motivation for our paper.

We think that the determinants of the cross-section of ETRs used in previous research so far carry over to the Dutch context. A particular feature of the Dutch financial reporting system (not present in the US) is that both public and private companies above a certain threshold have to file their financial statements. Public companies tend to be larger companies operating in a more international setting as private companies. Almost all listed companies are public too. In 
the next section we will formulate our hypotheses accordingly. After the formulation of the hypotheses we will provide discussion.

\subsection{Development of hypotheses.}

The discussion in the previous section motivates the following research hypotheses. The hypotheses are stated with direction where possible. We state the ceteris paribus version of each hypothesis. Precise variable definitions (e.g. in terms of REACH A mnemonics) will be given in Sections 4.3.2. and 4.3.3.. Additional Dutch context motivation is given where appropriate.

\section{H1: Company ETRs are related to company size}

Previous research relating to the firm size variable usually did not find equitable taxation for firms of different size. The findings are, however, not unidirectional. Therefore, the hypothesis is stated without sign. In the Netherlands, the possibility of defining a tax saving fiscal unity (parent/subsidiaries) within a company is more likely to be used in larger companies since they will have more subsidiaries. Also favourable tax rulings are more likely for larger firms as well as certain investment preferences. On the other side, certain investment preferences accrue disproportionally more to smaller firms.

H2: Company ETRs are inversely related to capital intensity (fixed assets/total assets)

Previous research, notably Gupta and Newberry (1997) and Stickney and McGee (1982), has found an inverse relationship between capital intensity and ETRs, due to tax preferences associated with investments in fixed assets, notably accelerated depreciation provisions. The Netherlands allows companies to depreciate fixed assets on a liberal basis. Also, there are tax preferences for investments in fixed assets. Therefore, an inverse relationship can be expected.

H3: Company ETRs are related to the extent of foreign operations (foreign sales/total sales)

The Netherlands has a system of participation exemptions for subsidiary income which specifically also applies to foreign subsidiaries. In effect the Netherlands has a territorial corporate income tax system (see, te Spenke (1995), section 4.5.1.). Depending on the weighted 
average of foreign income and the relevant foreign statutory tax rates, company ETRs will be positively or negatively related to the extent of foreign operations.

H4: Company ETRs are related to profitability (return on total assets)

Wilkie (1988) argues that tax preferences are associated with company characteristics, such as capital intensity, but not with profitability. Gupta \& Newberry (1997) argue for and find support for this association. Most Dutch tax preferences do not seem to be related to profitability, therefore we do not expect a sign for this hypothesis.

\section{H5: Company ETRs are inversely related to public companies}

H6: Company ETRs are inversely related to listed companies

As public companies tend to be listed, larger and more international companies they have more potential cloud and more international possibilities to reduce their tax burden. They also have an incentive to report high profits to shareholders while not increasing the tax burden at the same time. Most listed companies tend to be public companies, so the same relationship is expected for listed companies as for public companies.

\section{H7: Company ETRs are inversely related to leverage}

Interest costs are deductible, whereas dividend is not. Thus we expect companies with more leverage (and high interest expenses) to have lower ETRs.

H8: Company ETRs are inversely related to Net Operating Loss

H9: Company ETRs are inversely related to Negative Tax Expense

For hypotheses 1, 3 and 4 we have no expectation of direction. Since there was no important company income tax rate or tax rule change in the Netherlands in the 1994-1998 period, there is no need to formulate a tax rate/tax rule effect hypothesis. NOLs are measured in the years they occur. In an optimal setting NOL carryforwards should be considered. However, these are unavailable in Dutch financial accounting. 


\subsection{Discussion.}

One problematic aspect of average ETR research is the issue of the definition of the average ETR. As mentioned above, empirical outcomes may depend on specific definitions of the ETR. Wilkie and Limberg (1993) go so far as suggesting an alternative tax preferences variable, Tax Subsidy on Equity (TSE). This measure presumes corporate income taxes are related to stockholder's equity. Corporate income taxes are, however, based on income. We will therefore not use TSE in this paper. We will explain clearly the definition of our ETR variables in section 4.3.2.

Some authors have used an ETR variable based on pre-tax operating cash flow as denominator, notably Zimmerman (1983). The idea behind this is to correct for the effect of financial accounting method choices that may be interrelated to the explanatory variables of the ETR. We also use a cash flow based ETR in this paper.

A further caveat is in order here. The use of pre-tax financial accounting income as 'true' income in the calculation of the ETR also hinges on pre-tax financial accounting income being close to comprehensive (clean surplus) financial accounting income. This is probably more problematic in the Netherlands than in the US (see, Klaassen (1997, in Dutch), for a overview of 'dirty surplus' possibilities in the Netherlands). In our research design we control for 'dirty surplus', by using a second cash flow based ETR measure.

Yet other firm characteristics may of course affect ETRs. Gupta and Newberry (1997) suggest factors such as management share ownership, compensation policies and withincompany 'tax-minimization culture'. More management share ownership may lead to more aggressive tax planning, and manager compensation policies based on after-tax earnings may have an attenuating effect in this respect. We have not incorporated proxies for these factors below as such data is not readily available in Dutch financial reporting.

Lastly, ETRs focus on explicit taxes. Measurement of the total company tax burden should ideally also include consideration of implicit taxes that arise because of competition for tax preferences, driving down pre-tax returns. Implicit taxes are discussed by Scholes and 
Wolfson (1992). Callihan (1994, section 3.1.4.) provides an explanation. We have not incorporated implicit taxes below due to the measurement problems of corporate implicit taxes (Wilkie, 1992). 


\section{ETRs, the financial accounting treatment of company income tax in the Netherlands}

and the relevant statutory company tax rate.

\subsection{Financial accounting treatment of company income tax in the Netherlands.}

The only sources of data readily available to researchers outside the firm (who are not the tax authorities) for the calculation of company ETRs are published financial statements. Financial statements are used in this paper to calculate company ETRs in the Netherlands. The use of financial statements for the calculation of ETRs requires consideration of the financial accounting treatment of company income taxes. Dutch financial accounting practices are affected by financial accounting legislation and by financial accounting standard setting by the Council on Annual Reporting ('Raad voor de Jaarverslaggeving', RJ). While Dutch companies are obliged to follow the existing legal financial accounting requirements, RJ financial accounting standards are not obligatory ${ }^{4}$. There are both legal requirements and RJ standards for the financial accounting treatment of company income taxes. Below we will say that something is required, when such a requirement is a legal one or a $\mathrm{RJ}$ standard ${ }^{5}$.

Differences between financial accounting income and taxable income for a given year for firms arise in countries where there is independence in the determination of these two types of company income. Such independence exists in the Netherlands. Companies in the Netherlands are required to use interperiod tax allocation to deal with timing differences between financial accounting income and taxable income. Of course, both permanent and timing differences are possible in this context. When the effect of permanent differences on the tax rate implied by the income tax expense is 'considerable', the reasons for such permanent differences have to be explained in the financial statements notes section. Timing differences require the use of deferred taxes, which leads to deferred tax assets, and more typically to deferred tax liabilities. Separate identification of the current deferred tax expense in the income statement is not required. Hence, the current deferred tax expense can only be approximated by calculating the annual change in the deferred tax liability. Comprehensive allocation is required, and while using the present value of tax liabilities is allowed, almost always the nominal value is shown by Dutch companies. Finally, use of the liability method is required. A recent discussion in English of financial reporting regulation for income tax accounting in the Netherlands is Hoogendoorn (1996). The most recent survey of company practice in this area is Van der Gaar and Van der Tas (1991, in 
Dutch) for the year 1989. A recent exhaustive and clear treatment of income tax accounting in the Netherlands is Kampschoër (1997, in Dutch), who gives exact references to legal requirements and relevant RJ standards. The survey research of Van der Gaar and Van der Tas (1991) shows that Dutch firms generally stay close to the RJ standards, on a voluntary basis.

\subsection{Relevant statutory company income tax rate.}

We use data for the years 1994 to 1998. During that period the company income tax rate structure was as follows: 40 per cent of the first Hfl. 100.000 (prior to July 1994: Hfl. 250.000) and 35 per cent of the excess above that amount (Te Spenke, 1995, p.112) ${ }^{6}$. For all practical purposes, the statutory tax rate for the larger Dutch companies in our sample (see below) was near 35 percent in the 1994 - 1998 period.

\section{Research methods: data, sample, model, variables.}

\subsection{The REACH data file.}

The sample in this paper consists of a panel of companies whose financial statements were taken from the 2000 (release 53) CD-ROM REACH A data file for the period 1994-1998, the most recent period available. The REACH A data file is produced from financial statements of companies filing financial statements in the Netherlands with the local Chamber of Commerces registry. There are two REACH data files, REACH A and REACH B. REACH A contains the financial statement data for the roughly 5000 largest Dutch companies having to file with the Chamber of Commerce registries. REACH B encompasses the REACH A companies and also contains data about many smaller Dutch companies filing financial statements. The firm producing the REACH data file takes financial statements and transfers information from these to its own 'model' format of financial statements of which there are two types: an abbreviated model format and a complete model format. The existence of two formats is a consequence of the fact that Dutch financial reporting regulation has several disclosure regimes. The REACH complete model format corresponds to the disclosure regime for the largest companies. All items in the REACH complete model format are identified with a name and number identification. We will use these identifications below to define the variables used in this paper.

\subsection{Sample selection.}

In this paper we only use data for companies for which financial statements are available 
in the REACH complete model format. Five groups of observations in our sample were deleted. We deleted (i) non-trade and industry companies, (ii) companies with a special status, (iii)dependent companies, (iv) non-consolidated companies, (v) companies not having the public limited (NV) or private limited (BV) legal form and (vi) investment funds.

The first group was deleted as these have differing financial reporting. Non-trade and industry companies were deleted as these have differing financial reporting as well as differing tax legislation. Dependent companies are deleted as they are taxed at a (possibly differing) foreign tax rate. Non-consolidated companies were deleted as these companies are otherwise included twice in the sample. Non-incorporated companies as well as investment funds are not subject to the regular corporate tax regulations and were therefore excluded from the sample.

Finally, to create the 1994-1998 panel we only used companies for which all data (see below for the variable definitions) were available in all four years. Exclusion of companies with insufficient data, resulted in a final sample of 879 firms or 4,395 firm-years. A summary of the way the final sample was arrived at is given in table 1. A panel is used to be able to calculate the pooled ETRs over the entire period.

\section{Table 1}

\subsection{Multivariate model and variable definitions.}

\subsubsection{Model.}

We use the following general multivariate model. We omitted the company subscript $i$. The model will be estimated for ETR1 and ETR2.

ETR $_{\mathrm{t}}=\alpha_{\mathrm{t}}+\beta_{1}$ FSIZE $_{\mathrm{t}}+\beta_{2}$ CAPINT $_{\mathrm{t}}+\beta_{3}$ INVINT $_{\mathrm{t}}+\beta_{4}$ FOREIGN $_{\mathrm{t}}+\beta_{5}$ ROA $_{\mathrm{t}}+\beta_{6}$ LEVERAGE $+^{2}$ $\beta_{7}$ LISTED $_{\mathrm{t}}+\beta_{8}$ PUBLIC $+\varepsilon_{\mathrm{t}}$

The independent variables were treated as fixed effects. The following covariates were specified: $\mathrm{NOL}_{\mathrm{t}} ; \mathrm{NTE}_{\mathrm{t}} ; \mathrm{NOL}^{*} \mathrm{NTE}_{\mathrm{t}} ; \mathrm{NOL}^{*} \mathrm{FSIZE}_{\mathrm{t}} ; \mathrm{NTE}^{*} \mathrm{FSIZE}_{\mathrm{t}}$

The variable codings represent the following variables: $\mathrm{ETR}_{\mathrm{t}}=$ effective tax rate 1 or 2 (see below for explanation of ETR1 and ETR2); FSIZE $_{t}=$ firm size; CAPINT $_{t}=$ capital intensity; $\mathrm{INVINT}_{\mathrm{t}}=$ inventory intensity; FOREIGN ${ }_{\mathrm{t}}=$ international activities; $\mathrm{ROA}_{\mathrm{t}}=$ Return On Assets; LEVERAGE $_{\mathrm{t}}=$ leverage of company; $\mathrm{PUBLIC}_{\mathrm{t}}=$ public company; LISTED $_{\mathrm{t}}=$ listed company; 
$\mathrm{NOL}_{\mathrm{t}}=$ Financial Accounting Loss; $\mathrm{NTE}_{\mathrm{t}}=$ Negative Tax Expense; $\mathrm{NOL}^{*} \mathrm{NTE}_{\mathrm{t}}=$ Financial Accounting Loss * Negative Tax Expense; NOL*FSIZE $=$ Financial Accounting Loss * firm size; NTE*FSIZE $=$ Negative Tax Expense*firm size; $\alpha_{\mathrm{t}}=$ intercept and $\varepsilon_{\mathrm{t}}=$ error term; and $\mathrm{t}$ is a company-year between 1994 and 1998.

\subsubsection{Calculation of ETRs.}

As Dutch financial reporting only discloses deferred tax liabilities, but not deferred tax assets, we only use deferred tax liabilities in the ETR definitions. Furthermore, as the tax expense accrues to the entire income in the Dutch context we use the current tax expense as well as full financial accounting income before interest and taxes in our ETR measures. To control for possible differences in financial reporting between companies, we use an alternative ETR definition, based on cash flow. The ETR definitions are defined as:

ETR1 is: $\quad\left(1056-\left(1178_{\mathrm{t}}-1178_{\mathrm{t}-1}\right)\right) / 1034$

(tax expense-(deferred tax provision $_{\mathrm{t}}$-deferred tax provision $\left._{\mathrm{t}-1}\right)$ )/earnings before interest and taxes ETR2 is: $\quad\left(1056-\left(1178_{\mathrm{t}}-1178_{\mathrm{t}-1}\right)\right) /(1254-(1034-1055))$

(tax expense-(deferred tax provision $_{\mathrm{t}}$-deferred tax provision $\left.\left._{\mathrm{t}-1}\right)\right) /($ cash flow + interest charges and revenues)

in terms of REACH A item identification items.

\subsubsection{Determinants.}

1. FSIZE; firm size, defined as total assets (in REACH A identification: 1230).

2. CAPINT; capital intensity, which is tangible fixed assets divided by total assets (1090/1230).

3. FOREIGN; net foreign sales over net sales (1233/1003).

4. ROA; return on total assets (in mnemonics: 1055/1230).

5. LEVERAGE: leverage of the company defined as long term liabilities over total assets $(1189 / 1230)$.

6. PUBLIC: dummy variable that is 1 when the company is a public company and 0 otherwise. 7. QUOTED: dummy variable that is 1 when the company is a quoted company and 0 otherwise. 8. NOL; a dummy variable that is 1 when the company experiences a financial accounting loss for the current year and 0 when the company does not experience a net financial accounting loss (if $1055<0$ then $\mathrm{NOL}=1$; if $1055>=0$ then $\mathrm{NOL}=0$ ).

9. NTE; a dummy variable that is 1 when the company reports a negative tax expense and 0 otherwise (if $1056<0$ then $\mathrm{NTE}=1$; if $1056>=0$ then $\mathrm{NTE}=0$ ).

10 . NOL*NTE; dummy variable being 1 when the company experiences both a NOL as well as a NTE (if $1055<0$ and $1056<0$ then 1; 0 otherwise).

11. NOL*FSIZE; dummy interaction variable NOL and firm size.

12. NTE*FSIZE; dummy interaction variable NTE and firm size.

\subsubsection{Estimation Procedure.}


To investigate possible nonlinear relationships between determinants and ETRs as well as to control for the possible non-normal distribution of financial accounting data, a fixed effect generalised linear model (FEGLM) as well as a random effects generalised linear model (REGLM) were used to estimate our multivariate model of the relation between determinants and ETR. Sensitivity analysis using OLS regression was performed. FEGLM estimation results, as this model does not assume data are randomly distributed. The REGLM results support the FEGLM results. To test for nonlinear relationships the parametric variables were classified in deciles. As ETR ratios are easily distorted by extreme observations, ETRs below 0 were recoded to zero and ETRs above 1 were recoded to 1 , following the approach used by Gupta and Newberry (1997). 


\section{Results.}

\subsection{Descriptive and univariate results.}

Table 2 provides descriptive statistics for both ETR measures. For our sample, table 2 shows that the mean and median ETRs are clearly below the statutory tax rate of $35 \%$. Standard deviation and interquartile range show considerable variation however between companies in the sample. The cash flow based ETR2 measure is similar to ETR1 indicating that cash flow before interest is a good estimator of earnings before interest and taxes in this sample.

\section{Table 2}

Tables 3 and 4 provide descriptive univariate tests of the hypotheses. Table 4 does that separately for the dummy variables. Table 3 shows ETR1 and ETR2 means, medians and standard deviation for quartiles of company size, capital intensity, importance of foreign sales, ROA and leverage. Quartiles are in increasing order for the explanatory variables. Table 3 documents an inverse relationship between capital intensity-leverage and ETR1/2. That is, higher levels of capital intensity/ leverage appear to be related to lower levels of ETR1/2. Return on assets appears to have a positive relationship with ETR1/2.

\section{Table 3}

For the dummy variables industry, net operating loss, negative tax expense, NOL*NTE, ETR1 and ETR2 are given divided in table 4 for two subsets of companies, corresponding with the value 0 or 1 of the respective dummies. No differences between public/listed and nonpublic/non-listed companies are apparent. As expected, companies having a financial accounting loss, negative tax expense or a combination of these two, have lower ETRs.

\section{Table 4}

Tables 3 and 4 provide univariate results. It is clear of course that variables in our model are not unrelated. For instance, foreign sales may covary with company size. Table 5 therefore shows correlations between our explanatory variables. 


\section{Table 5}

Table 5 shows considerable correlations. Therefore a multivariate analysis is provided in the next section.

\subsection{Regression results.}

Table 6 summarizes the FEGLM results ${ }^{7}$. The results indicate that the overall explanatory power of our model is statistically significant for both ETR1 and ETR2 at the 5\% (ETR1) and 1\% (ETR2)-level. Using the earnings based ETR1 measure, only leverage (LEV) is significant at the $1 \%$-level. None of the covariates are significant. The multivariate model itself is significant at the $5 \%$-level but not at the 1\%-level. The multivariate model using the cash flow based ETR2 measure shows a significant capital intensity (CAPINT) as well as the covariates financial accounting loss (NOL), interaction financial accounting loss with negative tax expense (NOL*NTE) and interaction financial accounting loss with firm size (NOL*FSIZE). The model itself is significant at the $1 \%$-level.

Although ETR1 and ETR2 appear to measure the same effective tax rate (see table 2), they appear to be related differently to company characteristics. A partial explanation for these differences is the larger variance of the cash flow based ETR measure. With regard to capital intensity, the same effect is apparent using either ETR1 or ETR2, however, the ETR2 effect is stronger. For leverage, a similar but reverse relationship occurs. That is, the ETR1 measure has a significant inverse association where ETR2 has an inverse but not significant relationship. Detailed examination of the FEGLM data reveals that the leverage ETR1 relationship is consistently present in all deciles. This is in contrast, to the ETR2 capital intensity relationship that is mostly present in the first 3 deciles. That is, the $30 \%$ of companies with the lowest capital intensity cause the overall significant effect.

\section{Table 6}

\subsection{Sensitivity analysis}

The empirical results on the tests performed so far are influenced by the measurement design. Therefore, we provide additional sensitivity analysis investigating the influence of (i) the control variables, (ii) using an OLS regression model, (iii) deferred taxes and (iv) industry 
effects. For each sensitivity analysis we provide discussion.

Past research has mainly used multivariate models to assess relationships between ETR and company characteristics without employing control variables (Callihan, 1994). Our model does use control variables. To asses the impact of the inclusion of control variables on our empirical findings, we estimated a FEGLM without using covariates for both ETR1 and ETR2. Information on these models is reported in table 7.

\section{Table 7}

The results in table 7 confirm that our model using control variables is 'cleaner', that is, the relationships between company characteristics and ETRs is measured in a more consistent manner as (part of) the indirect effects are controlled for. This is shown by the higher $\mathrm{R}$ square and higher F-value of the original model. The relationships themselves are identical, but less significant in the model without control variables.

In order to use a FEGLM the explanatory variables had to be reclassified in ten deciles. To the extent this leads to a loss of information we perform a sensitivity analysis using OLS regression model for ETR1 and ETR2. These data are reported in table 8.

\section{Table 8}

The OLS regression results are not exactly similar to the FEGLM results, notably for ETR1 models. Where leverage was significant in the FEGLM model, this is not the case in the OLS model. In contrast, return on assets is significant. However, the explanatory power of the OLS model is lower. This also holds true for the ETR2 model, although the FEGLM and OLS model results for ETR2 are similar. Due to the fact, that the financial statement data are not normally distributed in our sample, OLS regression results have only limited validity.

Companies can use deferred taxes to 'smooth' their tax expenses. To the degree that this happens, our statistical analysis has only used current taxes in the ETR1/2 measure. To investigate whether companies use deferred taxes to 'smooth' their tax expenses we have calculated FEGLMs for ETR1/ETR2 calculated using the total tax expenses. The results for 
these 'gross' ETRs are reported in table 9.

\section{Table 9}

Using the 'gross' defined ETRs, especially the ETR1 model statistics improve. The R square and F-value improve considerably. For ETR2 these data are similar. Looking at the company characteristics using ETR1, leverage, quote and public are now all significant. These last two characteristics were not significant in the FEGLM. A possibly explanation is that listed firms (which are mostly also public firms) use the deferred tax expense in a different way than nonlisted firms, for instance to 'smooth' income. The ETR2 model shows significant relationships for capital intensity, return on assets and leverage. These last two were not significant in the FEGLM. Apparently the deferred tax expense is related to return on assets and leverage.

Tax preferences do not necessarily have to be related to company characteristics, they can also be related to specific industries. To investigate this possible relationship, all industries (on a 4 digit SIC code) were selected with more than ten companies (50 year observations) available. For these industries, mean and median ETR1/2 were calculated. The MannWhitney U test was used to determine whether these industries' ETRs were statistically significant different from the ETR1/2 for the entire sample. These data are reported in table 10.

\section{Table 10}

Apart from companies with SIC codes 5031 (lumber/wood) and 5271 (mobile home dealers), the selected industries reveal no significant differences from the median for the entire sample. This confirms our other findings with regard to neutrality of the Dutch corporate income tax system.

\section{Summary and conclusions.}

The aim of this paper was to investigate the extent of horizontal equity of Dutch corporate income taxes. Seven company characteristics and five control variables were used to explain Effective Tax Rates (ETRs) for a cross-sectional balanced panel of Dutch companies for the years 
1994 to 1998 . The seven company characteristics include firm size, capital intensity, extent of foreign operations, firm performance, leverage, being a public company and being a listed company. The five control variables include net operating loss status, negative tax expense status, interaction between net operating loss status and negative tax expense status, interaction between net operating loss status and firm size and interaction between negative tax expense status and firm size. Our empirical results confirm that the Dutch corporate income tax system provides significant amounts of tax subsidies to companies, but that the tax system is also fairly neutral, i.e. company ETRs can on average not be related to company characteristics. These findings are supported by additional sensitivity analysis. 
Table 1. Sample selection

panel a: initial selection

companies available in REACH A as of 2000,

trade and industry companies (detailed statements)

5,858

less: companies with a special status ${ }^{8} \quad 5,331$

less: dependent companies 2,387

less: non-consolidated companies 2,170

less: non-incorporated companies 2,136

less: investment funds 2,134

less: companies not available for balanced panel $\quad 879$ 
Table 2. Descriptive statistics for Effective Tax Rates 1 and 2

\begin{tabular}{lll}
\hline & & \multicolumn{1}{c}{$1994-1998$} \\
\hline & ETR1 & ETR2 \\
Mean & $\mathbf{0 . 2 6 7 9}$ & $\mathbf{0 . 2 6 5 8}$ \\
Standard Deviation & $\mathbf{0 . 2 0 2 5}$ & $\mathbf{0 . 2 1 4 5}$ \\
& & \\
Median & $\mathbf{0 . 2 6 4 7}$ & $\mathbf{0 . 2 4 7 7}$ \\
Interquartile range & $\mathbf{0 . 2 2 8 4}$ & $\mathbf{0 . 2 5 5 5}$ \\
N (firm years) & $\mathbf{8 3 7}(\mathbf{4 , 1 8 5 )}$ & $\mathbf{6 9 0}(\mathbf{3 , 4 5 0 )}$ \\
\hline
\end{tabular}

For variable definitions see section 4.3.1 
Table 3. Univariate descriptive results: mean and median ETRs for quartiles of explanatory variables

1994-1998 ( $\mathrm{n}=\mathbf{8 7 9}$ firms, 4,395 firm years)

\begin{tabular}{|l|c|l|l|l|l|}
\hline Sign & \multicolumn{1}{|c|}{$?$} & - & - & + & - \\
\hline Variable & FSIZE & CAPINT & FOREIGN & ROA & LEV \\
\hline 1st quartile & & & & & \\
\hline mean & $0.2557 / 0.2541$ & $0.3137 / 0.3487$ & $0.2947 / 0.2829$ & $0.2048 / 0.1990$ & $0.3286 / 0.3078$ \\
\hline median & $0.2596 / 0.2414$ & $0.3232 / 0.3133$ & $0.3100 / 0.2601$ & $0.0976 / 0.0632$ & $0.3449 / 0.2994$ \\
\hline std. dev. & $0.2060 / 0.2077$ & $0.1918 / 0.2515$ & $0.2050 / 0.2007$ & $0.2703 / 0.2972$ & $0.1876 / 0.1720$ \\
\hline 2nd quartile & & & & & \\
\hline mean & $0.2717 / 0.2591$ & $0.2717 / 0.3195$ & $0.2632 / 0.2745$ & $0.2204 / 0.2184$ & $0.2749 / 0.2777$ \\
\hline median & $0.2517 / 0.2348$ & $0.2755 / 0.3121$ & $0.2533 / 0.2479$ & $0.1993 / 0.1849$ & $0.2835 / 0.2478$ \\
\hline std. dev. & $0.2080 / 0.2185$ & $0.1871 / 0.2268$ & $0.1802 / 0.2017$ & $0.1981 / 0.1905$ & $0.1891 / 0.2215$ \\
\hline 3rd quartile & & & & & \\
\hline mean & $0.2842 / 0.2865$ & $0.2740 / 0.2270$ & $0.2587 / 0.3000$ & $0.2972 / 0.2959$ & $0.2381 / 0.2555$ \\
\hline median & $0.2795 / 0.2655$ & $0.2568 / 0.2387$ & $0.2624 / 0.2996$ & $0.2780 / 0.2599$ & $0.2345 / 0.2289$ \\
\hline std. dev. & $0.2272 / 0.2291$ & $0.2125 / 0.1611$ & $0.1477 / 0.1908$ & $0.1655 / 0.1787$ & $0.1926 / 0.2329$ \\
\hline 4th quartile & & & & & \\
\hline mean & $0.2591 / 0.2610$ & $0.2213 / 0.1876$ & $0.2845 / 0.2947$ & $0.3515 / 0.3491$ & $0.2101 / 0.2149$ \\
\hline median & $0.2647 / 0.2456$ & $0.2214 / 0.1620$ & $0.2642 / 0.2483$ & $0.3537 / 0.3422$ & $0.1696 / 0.1613$ \\
\hline std. dev. & $0.1669 / 0.2017$ & $0.2063 / 0.1778$ & $0.2142 / 0.2329$ & $0.1019 / 0.1213$ & $0.2222 / 0.2214$ \\
\hline
\end{tabular}

For variable definitions see section 4.3.1 


\section{Table 4. Univariate descriptive results: mean and median ETRs for the dummy explanatory variables}

1994-998( $\mathrm{n}=\mathbf{8 7 9}$ firms, 4,395 firm years)

\begin{tabular}{|l|l|l|l|l|l|}
\hline Expected sign & \multicolumn{1}{|c|}{-} & \multicolumn{1}{|c|}{-} & \multicolumn{1}{c|}{-} & \multicolumn{1}{|c|}{-} \\
\hline Variable & PUBLIC & QUOTED & NOL & NTE & NOL*NTE \\
\hline dummy $=0$ & BV & not-quoted & & & \\
\hline mean & $0.2697 / 0.2664$ & $0.2689 / 0.2648$ & $0.2696 / 0.2677$ & $0.2716 / 0.2714$ & $0.2652 / 0.2652$ \\
\hline median & $0.2570 / 0.2452$ & $0.2584 / 0.2408$ & $0.2697 / 0.2521$ & $0.2719 / 0.2535$ & $0.2647 / 0.2488$ \\
\hline std. dev. & $0.2129 / 0.2206$ & $0.2115 / 0.2206$ & $0.1886 / 0.1949$ & $0.1879 / 0.1957$ & $0.1895 / 0.1992$ \\
\hline dummy $=1$ & NV & quoted & & & \\
\hline mean & $0.2603 / 0.2631$ & $0.2622 / 0.2715$ & $0.2472 / 0.2427$ & $0.2274 / 0.2040$ & $0.3132 / 0.2760$ \\
\hline median & $0.2847 / 0.2547$ & $0.2755 / 0.2691$ & $0.0755 / 0.0012$ & $0.0542 / 0.0000$ & $0.1564 / 0.0055$ \\
\hline std. dev. & $0.1505 / 0.1878$ & $0.1373 / 0.1758$ & $0.3277 / 0.3828$ & $0.3211 / 0.3602$ & $0.3573 / 0.3979$ \\
\hline
\end{tabular}

For variable definitions see section 4.3.1 
Table 5. Correlation matrix ETR determinants (p-value between brackets)

\begin{tabular}{|c|c|c|c|c|c|c|c|c|}
\hline & public & quote & fsize & capint & foreign & roa & nolnte & nol \\
\hline quote & $0.83 * *$ & & & & & & & \\
\hline fsize & $0.57 * *$ & $-0.53 * *$ & & & & & & \\
\hline capint & $-0.09 * *$ & $0.10 * *$ & 0.01 & & & & & \\
\hline foreign & 0.09 & -0.09 & $0.17 * *$ & -0.08 & & & & \\
\hline roa & 0.04 & $-0.10 * *$ & 0.01 & $-0.16 * *$ & -0.11 & & & \\
\hline nolnte & -0.01 & 0.03 & $-0.09 * *$ & 0.02 & -0.04 & $-0.30 * *$ & & \\
\hline nol & -0.01 & 0.04 & $-0.09 * *$ & -0.00 & -0.04 & $-0.41 * *$ & $0.80 * *$ & \\
\hline nte & 0.03 & 0.03 & -0.05 & $0.09 *$ & -0.06 & $-0.31 * *$ & $0.79 * *$ & $0.62 * *$ \\
\hline
\end{tabular}

For variable definitions see section 4.3.1

*: significant at 5 percent level (two-tailed)

**: significant at $\mathbf{1}$ percent level (two-tailed) 
Table 6. Fixed effect generalised linear model results for ETRs on various determinants (t-values).

Model:

ETR1 or ETR2 $=\alpha_{t}+\beta_{1}$ FSIZE $_{t}+\beta_{2}$ CAPINT $_{t}+\beta_{3}$ FOREIGN $_{t}+\beta_{4}$ ROA $+\beta_{5}$ QUOTE $_{t}+$ $\beta_{6}$ PUBLIC $_{\mathrm{t}}+\varepsilon_{\mathrm{t}}$

Covariates:

$\mathrm{NOL}_{t} ; \mathrm{NTE}_{\mathrm{t}} ; \mathrm{NOL}^{*} \mathrm{NTE}_{\mathrm{t}} ; \mathrm{NOL}^{*} \mathrm{FSIZE}_{\mathrm{t}} ; \mathrm{NTE}^{*} \mathrm{FSIZE}_{\mathrm{t}}$

1994-1998 ( $\mathrm{n}=\mathbf{8 7 9}$ firms, 4,395 firm years)

Variable Predicted Actual ETR1 sign sign

$\begin{array}{lllllll} & & & \text { F-value } & \text { Sign } & \text { F-value } & \text { Sign } \\ \text { FSIZE } & ? & +/- & \mathbf{1 . 1 8 3} & \mathbf{0 . 3 1 6} & \mathbf{0 . 1 0 7} & \mathbf{0 . 9 9 8} \\ \text { CAPINT } & - & + & \mathbf{1 . 6 2 1} & \mathbf{0 . 1 1 4} & \mathbf{3 . 7 7 3} & \mathbf{0 . 0 0 0} * * \\ \text { FOREIGN } & ? & +/- & \mathbf{0 . 2 6 8} & \mathbf{0 . 9 8 2} & \mathbf{0 . 7 2 5} & \mathbf{0 . 6 8 6} \\ \text { ROA } & + & - & \mathbf{1 . 4 8 2} & \mathbf{0 . 1 5 9} & \mathbf{1 . 3 9 4} & \mathbf{0 . 1 9 6} \\ \text { LEV } & - & - & \mathbf{3 . 7 8 1} & \mathbf{0 . 0 0 0} * * & \mathbf{0 . 6 6 9} & \mathbf{0 . 7 3 6} \\ \text { QUOTE } & - & - & \mathbf{0 . 0 0 9} & \mathbf{0 . 9 2 6} & \mathbf{0 . 1 6 9} & \mathbf{0 . 6 8 2} \\ \text { PUBLIC } & - & - & \mathbf{0 . 0 3 4} & \mathbf{0 . 8 5 5} & \mathbf{0 . 1 5 7} & \mathbf{0 . 6 9 3}\end{array}$

ETR2

F-value
ETR1

F-value

NOL

NTE

NOL*NTE

NOL*FSIZE

NTE*FSIZE
0.776

0.121

0.974

0.831

0.137

ETR2

F-value Sign

$\begin{array}{lll}\text { Sign } & \text { F-value } & \text { Sign } \\ \text { 0.380 } & 4.163 & 0.043 * \\ 0.728 & 1.141 & 0.287 \\ 0.325 & 13.862 & 0.000^{*} * \\ 0.364 & 5.203 & 0.024^{*} \\ 0.712 & 1.914 & 0.169\end{array}$

R-square (adjusted R-square) $\quad 0.351(0.133) \quad 0.412(0.214)$

F-statistic (p-value) $1.612(0.015 *) \quad 2.078(0.000 * *)$

* significant at the 5\% level (two-tailed)

** significant at the $1 \%$ level (two-tailed)

For variable definitions see section 4.3.1 
Table 7. Fixed effect generalised linear model results for ETRs on various determinants excluding covariates (t-values).

Model:

ETR1 or ETR2 $=\alpha_{t}+\beta_{1}$ FSIZE $_{t}+\beta_{2}$ CAPINT $_{t}+\beta_{3}$ FOREIGN $_{t}+\beta_{4}$ ROA $+\beta_{5}$ QUOTE $_{t}+$ $\beta_{6}$ PUBLIC $_{t}+\varepsilon_{t}$

1994-1998 ( $\mathrm{n}=\mathbf{8 7 9}$ firms, 4,395 firm years)

Variable Predicted Actual ETR1 sign sign

$\begin{array}{lllllll} & & & \text { F-value } & \text { Sign } & \text { F-value } & \text { Sign } \\ \text { FSIZE } & ? & +/- & \mathbf{1 . 3 6 9} & \mathbf{0 . 2 2 2} & \mathbf{0 . 3 8 7} & \mathbf{0 . 9 0 9} \\ \text { CAPINT } & - & + & \mathbf{1 . 7 6 8} & \mathbf{0 . 0 7 9} & \mathbf{3 . 1 1 5} & \mathbf{0 . 0 0 2} * * \\ \text { FOREIGN } & ? & +/- & \mathbf{0 . 3 2 2} & \mathbf{0 . 9 6 7} & \mathbf{0 . 5 5 0} & \mathbf{0 . 8 3 6} \\ \text { ROA } & + & - & \mathbf{1 . 2 8 6} & \mathbf{0 . 2 4 9} & \mathbf{1 . 2 9 4} & \mathbf{0 . 2 4 4} \\ \text { LEV } & - & - & \mathbf{3 . 4 8 5} & \mathbf{0 . 0 0 1 * *} & \mathbf{0 . 6 3 3} & \mathbf{0 . 7 6 8} \\ \text { QUOTE } & - & - & \mathbf{0 . 3 4 5} & \mathbf{0 . 5 5 8} & \mathbf{0 . 0 0 2} & \mathbf{0 . 9 6 9} \\ \text { PUBLIC } & - & - & \mathbf{0 . 9 3 4} & \mathbf{0 . 3 3 5} & \mathbf{0 . 0 9 2} & \mathbf{0 . 7 6 3}\end{array}$

R-square (adjusted R-square)

F-statistic (p-value)

$0.305(0.102)$

$1.505(0.036 *)$

* significant at the 5\% level (two-tailed)

** significant at the $1 \%$ level (two-tailed)

For variable definitions see section 4.3.1

\section{ETR2}

F-value

3.115

0.909

0.836

0.244

0.969

0.092 
Table 8. OLS regression model results for ETRs on various determinants (t-values).

Model:

ETR1 or ETR2 $=\alpha_{t}+\beta_{1}$ FSIZE $_{t}+\beta_{2}$ CAPINT $_{t}+\beta_{3}$ FOREIGN $_{t}+\beta_{4}$ ROA $+\beta_{5}$ QUOTE $_{t}+$ $\beta_{6}$ PUBLIC $_{\mathrm{t}}+\beta_{7} \mathrm{NOL}+\beta_{8} \mathrm{NTE}+\beta_{9}$ NOL $*$ NTE $+\beta_{10} \mathrm{NOL} *$ FSIZE $+\beta_{11}$ NTE*FSIZE $+\varepsilon_{\mathrm{t}}$

1994-1998 ( $\mathrm{n}=\mathbf{8 7 9}$ firms, 4,395 firm years)

Variable Predicted Actual ETR1 sign sign

$\begin{array}{lllllll} & & & \text { t-value } & \text { Sign } & \text { t-value } & \text { Sign } \\ \text { FSIZE } & ? & + & \mathbf{0 . 1 8 0} & \mathbf{0 . 8 5 8} & \mathbf{0 . 6 3 5} & \mathbf{0 . 5 2 6} \\ \text { CAPINT } & - & - & -\mathbf{1 . 5 3 8} & \mathbf{0 . 1 2 6} & \mathbf{- 4 . 2 8 5} & \mathbf{0 . 0 0 0 * *} \\ \text { FOREIGN } & ? & - & \mathbf{- 0 . 0 5 3} & \mathbf{0 . 9 5 8} & \mathbf{- 1 . 2 6 9} & \mathbf{0 . 2 0 6} \\ \text { ROA } & + & + & \mathbf{2 . 8 8 6} & \mathbf{0 . 0 0 4} * * & \mathbf{5 . 9 4 4} & \mathbf{0 . 0 0 0 * *} \\ \text { LEV } & - & - & -\mathbf{0 . 8 5 9} & \mathbf{0 . 3 9 2} & \mathbf{- 0 . 4 6 2} & \mathbf{0 . 6 4 5} \\ \text { QUOTE } & - & - & -\mathbf{0 . 4 9 0} & \mathbf{0 . 6 2 5} & \mathbf{- 1 . 9 0 1} & \mathbf{0 . 0 5 9} \\ \text { PUBLIC } & - & + & \mathbf{0 . 0 0 3} & \mathbf{0 . 9 9 8} & \mathbf{1 . 3 4 4} & \mathbf{0 . 1 8 0} \\ \text { NOL } & & & -\mathbf{0 . 2 1 8} & \mathbf{0 . 8 2 8} & \mathbf{- 0 . 0 7 6} & \mathbf{0 . 9 3 9} \\ \text { NTE } & & & \mathbf{- 0 . 9 5 8} & \mathbf{0 . 3 3 9} & \mathbf{- 0 . 0 1 7} & \mathbf{0 . 9 8 6} \\ \text { NOL*NTE } & & \mathbf{2 . 7 5 0} & \mathbf{0 . 0 0 7} * * & \mathbf{2 . 3 5 3} & \mathbf{0 . 0 2 0} \\ \text { NOL*FSIZE } & & \mathbf{0 . 0 4 2} & \mathbf{0 . 9 6 6} & \mathbf{- 0 . 0 8 9} & \mathbf{0 . 9 2 9} \\ \text { NTE*FSIZE } & & \mathbf{0 . 6 3 3} & \mathbf{0 . 5 2 8} & \mathbf{- 0 . 4 7 9} & \mathbf{0 . 6 3 2}\end{array}$

\begin{tabular}{lll} 
R-square (adjusted R-square) & $0.132(0.079)$ & $0.340(0.303)$ \\
F-statistic (p-value) & $2.518(0.004 * *)$ & $9.195(0.000 * *)$ \\
\hline
\end{tabular}

* significant at the 5\% level (two-tailed)

** significant at the $1 \%$ level (two-tailed)

For variable definitions see section 4.3.1 
Table 9. Fixed effect generalised linear model results for gross ETRs on various determinants (t-values).

Model:

gross ETR1 or ETR2 $=\alpha_{\mathrm{t}}+\beta_{1}$ FSIZE $_{\mathrm{t}}+\beta_{2} \mathrm{CAPINT}_{\mathrm{t}}+\beta_{3}$ FOREIGN $_{\mathrm{t}}+\beta_{4}$ ROA $+\beta_{5}$ QUOTE $_{\mathrm{t}}+$ $\beta_{6}$ PUBLIC $_{t}+\varepsilon_{t}$

Covariates:

$\mathrm{NOL}_{\mathrm{t}} ; \mathrm{NTE}_{\mathrm{t}} ; \mathrm{NOL}^{*} \mathrm{NTE}_{\mathrm{t}} ; \mathrm{NOL}^{*} \mathrm{FSIZE}_{\mathrm{t}} ; \mathrm{NTE}^{*} \mathrm{FSIZE}_{\mathrm{t}}$

1994-1998 ( $\mathrm{n}=\mathbf{8 7 9}$ firms, 4,395 firm years)

Variable Predicted Actual ETR1

ETR2

$\begin{array}{lllllll} & & & \text { F-value } & \text { Sign } & \text { F-value } & \text { Sign } \\ \text { FSIZE } & ? & +/- & \mathbf{0 . 5 7 1} & \mathbf{0 . 8 0 1} & \mathbf{0 . 9 4 5} & \mathbf{0 . 4 8 1} \\ \text { CAPINT } & - & + & \mathbf{1 . 0 7 1} & \mathbf{0 . 3 8 6} & \mathbf{5 . 1 5 4} & \mathbf{0 . 0 0 0 * *} \\ \text { FOREIGN } & ? & +/- & \mathbf{0 . 7 7 6} & \mathbf{0 . 6 3 9} & \mathbf{0 . 4 7 1} & \mathbf{0 . 8 9 3} \\ \text { ROA } & + & - & \mathbf{1 . 5 7 2} & \mathbf{0 . 1 2 7} & \mathbf{1 . 9 5 5} & \mathbf{0 . 0 4 7} \\ \text { LEV } & - & - & \mathbf{4 . 8 6 8} & \mathbf{0 . 0 0 0 * *} & \mathbf{2 . 0 6 1} & \mathbf{0 . 0 3 5} \\ \text { QUOTE } & - & - & \mathbf{8 . 3 1 9} & \mathbf{0 . 0 0 4} * * & \mathbf{0 . 2 3 3} & \mathbf{0 . 6 3 0} \\ \text { PUBLIC } & - & - & \mathbf{6 . 1 1 1} & \mathbf{0 . 0 1 4} * & \mathbf{0 . 0 6 3} & \mathbf{0 . 8 0 3}\end{array}$

Covariates:

ETR1

ETR2

NOL

F-value

Sign

F-value

Sign

NTE

0.818

0.367

0.790

0.375

NOL*NTE

3.140

0.078

1.065

0.304

NOL*FSIZE

9.686

0.002 **

2.608

0.108

NTE*FSIZE

0.160

0.690

1.778

0.184

4.538

$0.035 *$

1.293

0.257

R-square (adjusted R-square) $\quad 0.542(0.409)$

$0.390(0.211)$

F-statistic (p-value)

$4.062(0.000 * *)$

$2.179(0.000 * *)$

* significant at the 5\% level (two-tailed)

** significant at the $1 \%$ level (two-tailed)

For variable definitions see section 4.3.1 
Table 10 Mean and median ETR1/2 for various SIC industries.

\begin{tabular}{|c|c|c|c|c|c|}
\hline SIC code & Industry & $\begin{array}{c}\text { Mean } \\
\text { ETR1/2 }\end{array}$ & $\begin{array}{l}\text { Median } \\
\text { ETR1/2 }\end{array}$ & $\begin{array}{c}\text { Mann- } \\
\text { Whitney U } \\
\text { test }\end{array}$ & Significance \\
\hline 1521 & $\begin{array}{l}\text { General Contractors- } \\
\text { Single-Family Houses }\end{array}$ & $0.2954 / 0.2740$ & $0.2809 / 0.2756$ & $-0.890 /-1.158$ & $0.373 / 0.247$ \\
\hline 1731 & Electrical Work & $0.2492 / 0.2773$ & $0.3012 / 0.2769$ & $-0.097 /-0.035$ & $0.923 / 0.972$ \\
\hline 2731 & $\begin{array}{l}\text { Books: Publishing, or } \\
\text { Publishing and Printing }\end{array}$ & $0.3059 / 0.3372$ & $0.2794 / 0.3512$ & $-0.806 /-1.169$ & $0.420 / 0.242$ \\
\hline 3441 & Fabricated Structural Metal & $0.2830 / 0.2504$ & $0.2755 / 0.2061$ & $-0.082 /-0.113$ & $0.935 / 0.910$ \\
\hline 4119 & $\begin{array}{l}\text { Local Passenger } \\
\text { Transportation }\end{array}$ & $0.2826 / 0.1508$ & $0.2759 / 0.1551$ & $-0.287 /-1.713$ & $0.774 / 0.087$ \\
\hline 5012 & $\begin{array}{l}\text { Automobiles and Other } \\
\text { Motor Vehicles }\end{array}$ & $0.2493 / 0.2563$ & $0.2573 / 0.2403$ & $-0.129 /-0.628$ & $0.897 / 0.530$ \\
\hline 5031 & $\begin{array}{l}\text { Lumber, Plywood, } \\
\text { Millwork, and Wood } \\
\text { Panels }\end{array}$ & $0.3820 / 0.2657$ & $0.2781 / 0.2473$ & $-0.744 /-2.853$ & $0.457 / 0.004 * *$ \\
\hline 5082 & $\begin{array}{l}\text { Construction and Mining } \\
\text { (Except Petroleum) } \\
\text { Machinery and Equipment }\end{array}$ & $0.3005 / 0.2484$ & $0.2859 / 0.2986$ & $-0.974 /-1.292$ & $0.330 / 0.196$ \\
\hline 5149 & $\begin{array}{l}\text { Groceries and Related } \\
\text { Products }\end{array}$ & $0.1867 / 0.2789$ & $0.1670 / 0.2537$ & $-1.101 /-0.940$ & $0.271 / 0.347$ \\
\hline 5271 & Mobile Home Dealers & $0.1442 / 0.1538$ & $0.1653 / 0.1359$ & $-2.734 /-2.791$ & $0.006 * * / 0.005^{* *}$ \\
\hline 5411 & Grocery Stores & $0.3005 / 0.2264$ & $0.2906 / 0.2504$ & $-0.378 /-0.077$ & $0.706 / 0.938$ \\
\hline
\end{tabular}

* significant at the 5\% level (two-tailed)

** significant at the $1 \%$ level (two-tailed) 


\section{References.}

Belastingdienst, 1997, Verschillen tussen de fiscale en vennootschappelijke jaarrekening, Belastingdienst, 's-Gravenhage.

Banning, G., T.Meeus, 1998, De onzichtbare hand van de politiek, Balans, Amsterdam.

Calihan, D., 1994, Corporate effective tax rates: a synthesis of the literature, in: Journal of Accounting Literature, 13, pp. 1-43.

van der Gaar en van der Tas,

Guidelines, 1995, Guidelines for annual reporting in the Netherlands, Kluwer, Deventer.

Gupta, S., K.Newberry, 1997, Determinants of the variability in corporate effective tax rates: evidence from logitudinal data, in: Journal of Accounting and Public Policy, 16, pp. 1-34, 1997

Holland, K., 1998, Accounting policy choice: the relationship between corporate tax burdens and company size, in: Journal of Business Finance \& Accounting, 25, 3, pp. 265-288.

Hoogendoorn, M., 1996, Accounting and taxation in the Netherlands, in: European Accounting Review, 5, Supplement, pp. 871-882.

Kampschoër, G, 1997, Belastingen, in: M.Hoogendoorn, et.al., Externe verslaggeving in theorie en praktijk, Delwel, Den Haag, pp. 464-499.

Klaassen, J, 1997, Financiële positie, resultaat en financiële performance, in: MAB, 1997, 10, pp.508-516.

Omer, T, K.Molloy, D.Ziebart, 1991, Measurement of effective corporate tax rates using financial statement information, in: Journal of the American Taxation Association, 13, 1, pp. $57-72$.

Pleskp, C., 1999, An evaluation of alternative measures of corporate tax rates, working paper, MIT

Porcano, T., 1986, Corporate tax rates: progressive, proportional, or regressive, in: Journal of the American Taxation Association, 7, 2, pp. 17-31.

Scholes, M., M.Wolfson, 1992, Taxes and Business Strategy: A Planning Approach, Prentice Hall, Englewood Cliffs.

Shevlin, T., S.Porter, 1992, The corporate tax comeback in 1987: some further evidence, in: Journal of the American Taxation Association, 14, 1, pp. 58-79.

Stickney, C., V. McGee, 1982, Effective corporate tax rates: the effect of size, capital intensity, leverage, and other factors, in: Journal of Accounting and Public Policy, 1, pp. 125152. 
Te Spenke, G., 1995, Taxation in the Netherlands, Kluwer, Deventer/Boston.

Van de Gaar, E, L.Van der Tas, 1991, De verwerking van belasting naar de winst, in:

J.Dijksma, C.Knoops, eds., Jaar-in, jaar-uit 5, Wolters-Noordhoff, Groningen.

Wang, S., 1991, The Relation Between Firm Size \& Effective Tax Rates: a Test of Firms'

Political Success, in: The Accounting Review, 66, 1, pp. 158-169.

Wilkie, P., 1988, Corporate average effective tax rates and inferences about relative taxes, in: Journal of the American Taxation Association, 10, 1, pp.75-88.

Wilkie, P., 1992, Empirical evidence of implicit taxes in the corporate sector, in: Journal of the American Taxation Association, 14, 2, pp. 97-116.

Wilkie, P, S.Limberg, 1990, The relationship between firm size and effective tax rate: a reconciliation of Zimmerman [1983] and Porcano [1986], in: Journal of the American Taxation Association, 11, 2, pp. 76-91.

Wilkie, P., S.Limberg, 1993, Measuring explicit tax (dis)advantage for corporate taxpayers: an alternative to average effective tax rates, in: Journal of the American Taxation Association, 15, 1, pp. 46-71.

Zeff, S., F.Van der Wel, K.Camfferman, 1992, Company Financial Reporting: a historical and comparative study of the Dutch regulatory process, Elsevier Science Publishers, Amsterdam.

Zimmerman, J., 1983, Taxes and firm size, in: Journal of Accounting and Economics, 5, pp. 119-149. 
${ }^{1}$ One of the best-known such political action groups in the United States is the Citizens for Tax Justice (CTJ) movement.

${ }^{2}$ For an account of the technolease arrangement, see Banning and Meeus (1998, in Dutch).

${ }^{3}$ These aggregated results show a significant difference between the financial accounting income and taxable income where taxable income tends be lower than financial accounting income (Belastingdienst, 1997).

${ }^{4}$ See, Zeff, Van der Wel and Camfferman (1992) for an insightful history of Dutch financial reporting regulation and for a description of the current situation.

${ }^{5}$ Dutch financial reporting law and RJ standards are available in English in Guidelines (1995).

${ }^{6}$ In 1996 the $40 \%$ tax rate was lowered to $37 \%$ and in 1997 to $36 \%$. From $199835 \%$ is the uniform corporate income tax rate in the Netherlands.

${ }^{7}$ A random effects generalized linear model (REGLM) (not reported) produces identical empirical results.

7 Companies with a special status represent companies being merged, acquired, discontinued, bankrupt and

defined as small. 